\title{
Effect of Somatic Cell Count on Proteolysis and Lipolysis in Pasteurized Fluid Milk During Shelf-Life Storage ${ }^{1}$
}

\author{
M. V. Santos, ${ }^{\star}$ Y. Ma,† and D. M. Barbano† \\ *Departamento de Nutrição e Produção Animal, Faculdade de Medicina Veterinária e Zootecnia, \\ Universidade de São Paulo, Pirassununga, SP, Brazil \\ †Northeast Dairy Foods Research Center, \\ Department of Food Science, \\ Cornell University, Ithaca, NY, 14853
}

\section{ABSTRACT}

The general goal of this research was to provide fluid milk processors with data to enable them to estimate the economic benefits they might derive from longer fluid milk shelf-life or new marketing opportunities due to a reduction in raw milk SCC. The study objectives were: 1) to measure the time in days for pasteurized homogenized $2 \%$ milk to achieve a level of lipolysis and proteolysis caused by native milk enzymes present in milks of different somatic cell count (SCC) at 0.5 and $6^{\circ} \mathrm{C}$ that would be sufficient to produce an off-flavor, 2) to determine whether milk fat content (i.e., 1, 2, and $3.25 \%$ ) influences the level of proteolysis or lipolysis caused by native milk enzymes at $6^{\circ} \mathrm{C}$, and 3 ) to determine the time in days for milks containing $2 \%$ fat with different SCC to undergo sufficient lipolysis or proteolysis to produce an off-flavor due to the combination of the action of native milk enzymes and microbial growth at 0.5 and $6^{\circ} \mathrm{C}$. In experiment 1 , pasteurized, homogenized milks, containing $2 \%$ fat were prepared from raw milk containing four different SCC levels from $<100,000$ to $>1,000,000$ cell $/ \mathrm{ml}$. Each of the four milks was stored at 0.5 and $6^{\circ} \mathrm{C}$ for $61 \mathrm{~d}$. In experiment 2 , pasteurized, homogenized milks containing 1,2 , and $3.25 \%$ fat were prepared starting from two raw milks containing two different SCC levels, one $<100,000$ and the other $>1,000,000 \mathrm{cells} / \mathrm{ml}$. In experiment 3 , pasteurized, homogenized $2 \%$ fat milks were prepared starting from raw milks containing two different SCC levels, one $<100,000$ and the other $>1,000,000$ cells $/ \mathrm{ml}$. For experiments 1 and 2, all milks were preserved with potassium dichromate to prevent microbial growth but to allow the activity of native milk proteases and lipases during

Received September 4, 2002.

Accepted January 27, 2003.

Corresponding author: D. M. Barbano; e-mail: dmb37@cornell.edu.

${ }^{1}$ Use of names, names of ingredients, and identification of specific models of equipment is for scientific clarity and does not constitute any endorsement of product by authors, Cornell University, Universidade de São Paulo or the Northeast Dairy Foods Research Center. storage. For experiment 3, one set of milk was preserved with potassium dichromate to prevent microbial growth but to allow the activity of native milk proteases and lipases, and a second set of milk was unpreserved during storage at 0.5 and $6^{\circ} \mathrm{C}$ for $29 \mathrm{~d}$. Based on previous work, an off-flavor due to proteolysis was detected by $50 \%$ of panelists when the decrease in casein as a percentage of true protein $(\mathrm{CN} / \mathrm{TP})$ was $>4.76 \%$. Our data indicated (assuming $50 \%$ of consumers would detect an off-flavor when CN/TP decreases 5\%) that pasteurized milk containing $2 \%$ fat would develop an off-flavor at a time long after 61 and at $54 \mathrm{~d}$ for the low SCC milk, and at about 54 and $19 \mathrm{~d}$ for the high SCC milk, at 0.5 and $6^{\circ} \mathrm{C}$, respectively. Previous research reported that $34 \%$ of panelists could detect an off-flavor in milk containing $2 \%$ fat due to lipolysis at a (free fatty acid) FFA concentration of $0.25 \mathrm{meq} / \mathrm{kg}$ of milk. Based on these results, it was estimated in the present study that $34 \%$ of panelists would detect an off-flavor in a $2 \%$ fat pasteurized milk with low SCC at a time long after 61 and just after $61 \mathrm{~d}$ at 0.5 and $6^{\circ} \mathrm{C}$, respectively, while for milk with high SCC, an off-flavor would be detected by $34 \%$ of panelists at slightly longer than 61 and $35 \mathrm{~d}$ at 0.5 and $6^{\circ} \mathrm{C}$, respectively. The combination of low SCC milk and low storage temperature when coupled with processing technology to produce very low initial bacteria count in fluid milk could produce fluid milk that will maintain flavor quality for more than $61 \mathrm{~d}$ of storage at temperatures $<6^{\circ} \mathrm{C}$.

(Key words: somatic cell count, proteolysis, lipolysis, pasteurized fluid milk quality)

Abbreviation key: $\mathbf{C C}=$ coliform count, $\mathbf{C N} / \mathbf{T P}=$ casein as a percentage of true protein, $\mathbf{D}(\mathbf{0 . 9})=$ globules smaller than this diameter contain $90 \%$ of the volume of fat, $\mathbf{N C N}=$ noncasein nitrogen, $\mathbf{P B C}=$ psychrotrophic bacterial count, $\mathbf{S P C}=$ standard plate count, $\mathbf{T P}=$ true protein, $\mathbf{V M D}=$ volume mean diameter.

\section{INTRODUCTION}

Bovine mastitis has been described as the most costly disease in the dairy industry, resulting in reduced milk 
yield, increased cost of milk production, and reduced milk quality (National Mastitis Council, 1996) and is defined as an inflammation of the mammary gland in the response to invading microorganisms. Milk SCC is a commonly used indicator of the prevalence of subclinical mastitis in dairy cows (National Mastitis Council, 1996). Due to the inflammatory response during mastitis, secretion of milk components that are synthesized de novo is reduced and an influx of blood components into the milk occurs (Kitchen, 1981). These blood components include a variety of enzymes, which alter milk composition through breakdown of casein and milk fat (Grieve and Kitchen, 1985). The most important of these enzymes is plasmin, a milk protease that degrades casein (Saeman et al., 1988). The effects of elevated milk SCC on the yield and overall quality of milk and dairy products include poor coagulating properties and lower cheese yield (Politis and Ng Kwai Hang, 1988b; Barbano et al., 1991; Klei et al., 1998), increased loss of fat and casein in whey (Politis and Ng Kwai Hang, 1988a; Barbano et al., 1991) and reduced sensory quality and shelf-life (Munro et al., 1984). Cheese manufacturers have paid extra for low SCC milk because the results of research studies (combined with their own observations) have provided quantitative relationships between increase in milk SCC and decrease in cheese yield. This enables a cheese maker to calculate the economic value of milk SCC reduction for milk payment purposes. Recently, it was demonstrated that mastitis adversely affects the quality of pasteurized fluid milk by accelerating the development of sensory defects such as rancidity and bitterness (Ma et al., 2000). These defects are caused by lipolysis and proteolysis, respectively.

The threshold for detection of off-flavors caused by lipolysis and proteolysis due to the action of native milk enzymes has been investigated by Santos et al. (2003). They determined that $34 \%$ of panelists could detect an off-flavor due to lipolysis in $2 \%$ fat milk at a FFA concentration of $0.25 \mathrm{meq} / \mathrm{kg}$ of milk. Ma et al. (2000) estimated that the sensory threshold for detection of off-flavor related to proteolysis in $2 \%$ fat milk was approximately a $4 \%$ decrease in casein as a percentage of true protein (CN/TP). Santos et al. (2003) determined that the sensory threshold in skim milk for off-flavor produced by the activity of native milk proteases was approximately a $4.76 \%$ decrease in CN/TP. These objective measures of lipolysis and proteolysis provide useful chemical benchmarks of when off-flavors will be detected and they are used in the current study.

The general goal of this research was to provide fluid milk processors with data to enable them to estimate the economic benefits they might derive from longer fluid milk shelf-life or new marketing opportunities due to a reduction in raw milk SCC. The present study was designed to determine the effects of raw milk SCC on the proteolysis and lipolysis of preserved pasteurized milk stored at refrigeration temperatures. The specific objectives were: 1 ) to measure the time in days for pasteurized homogenized $2 \%$ milk to achieve a level of lipolysis and proteolysis caused by native milk enzymes present in milks of different SCC at 0.5 and $6^{\circ} \mathrm{C}$ that would be sufficient to produce an off-flavor, 2) to determine whether milk fat content (i.e., 1, 2, and 3.25\%) influences the level of proteolysis or lipolysis caused by native milk enzymes at $6^{\circ} \mathrm{C}$, and 3 ) to determine the time in days for milks containing $2 \%$ fat with different SCC to undergo sufficient lipolysis or proteolysis to produce an off-flavor due to the combination of the action of native milk enzymes and microbial growth at 0.5 and $6^{\circ} \mathrm{C}$.

\section{MATERIALS AND METHODS}

\section{Experimental Design}

Experiment 1. Pasteurized, homogenized milks, containing $2 \%$ fat were prepared starting from raw milk containing four different SCC levels from $<100,000$ to $>1,000,000$ cells $/ \mathrm{ml}$. All milks were preserved with potassium dichromate to prevent microbial growth but to allow the activity of native milk proteases and lipases, during storage (Senyk et al., 1985). Portions of each of the four milks were stored at 0.5 and $6^{\circ} \mathrm{C}$ for $61 \mathrm{~d}$. The extent of proteolysis and lipolysis were measured throughout the storage period. The experiment was done twice starting with milk from two different groups of cows.

Experiment 2. Pasteurized, homogenized milks containing 1,2 , and $3.25 \%$ fat were prepared starting from raw milks containing two different SCC levels, one $<100,000$ and the other $>1,000,000$ cells $/ \mathrm{ml}$. All milks were preserved with potassium dichromate to prevent microbial growth but to allow the activity of native milk proteases and lipases, during storage at $6^{\circ} \mathrm{C}$ for $57 \mathrm{~d}$. The extent of proteolysis and lipolysis were measured throughout the storage period. The experiment was done twice starting with milk from two different groups of cows.

Experiment 3. Pasteurized, homogenized 2\% fat milks were prepared starting from raw milks containing two different SCC levels, one $<100,000$ and the other $>1,000,000$ cells $/ \mathrm{ml}$. One set of milk was preserved with potassium dichromate to prevent microbial growth but to allow the activity of native milk proteases and lipases and a second set of the same milks were unpreserved, during storage. Each of the milks was stored at 0.5 and $6^{\circ} \mathrm{C}$ for $29 \mathrm{~d}$. The extent of proteolysis and lipolysis were measured throughout the storage period. 
The experiment was done twice starting with milk from two different groups of cows.

\section{Cow Selection}

Milks from sixty Holstein cows from the Cornell Teaching and Research Center were screened for milk fat and protein [(Association of Official Analytical Chemists, 2000); AOAC method number 33.2.31; 972.16], and SCC [(Association of Official Analytical Chemists, 2000); AOAC method number 17.13.01; 978.26] $3 \mathrm{~d}$ before milk collection. Eight cows that produced milk with low SCC $(<100,000$ cells $/ \mathrm{ml})$ and nine cows that produced milk with high SCC $(>800,000$ but $<1,200,000$ cells $/ \mathrm{ml}$ ) were selected, while maintaining similar average milk fat and protein content for milk produced by the two groups. The milks from all cows were collected on the same day at the same milking within a replicate in experiments 1,2 , and 3 . The replicates were done in different weeks within the same month. Within replicates 1 and 2, the same raw milks were used for all three experiments. All cows were on $3 \times$ milking regimen, averaging $182 \pm 119 \mathrm{DIM}$ and 1.7 \pm 1.2 lactations (parity).

\section{Milk Collection and Commingling}

On the day of milk collection, all the milk from one milking was collected separately from each cow and milk yield was recorded. Raw milk from individual cows was immediately transported to Cornell Food Science Department Pilot Plant and cooled to $4^{\circ} \mathrm{C}$. A sample of milk from each cow was taken and preserved with bronopol (Preservative System Limited, San Francisco, CA) and tested for SCC [(Association of Official Analytical Chemists, 2000); AOAC method number 17.13.01, 978.26].

Based on results of milk SCC for individual cows on the collection day, raw unpreserved individual cow milks were commingled in two batches: one with low SCC (batch A, eight cows, average 26,000 cells $/ \mathrm{ml}$ ) and one with high SCC (batch D, eight cows, average $1,113,000$ cells $/ \mathrm{ml}$ ). Two intermediate levels of milk SCC were obtained by mixing appropriate amounts of milks A and D, producing batch B (average 376,000 cells $/ \mathrm{ml}$ ) and batch C (average 726,000 cells $/ \mathrm{ml}$ ). Samples of all four batches were preserved with bronopol tablets (Preservative System Limited, San Francisco, CA) and tested for SCC levels. The four batches of commingled raw unpreserved milk were stored overnight at $4^{\circ} \mathrm{C}$.

\section{Milk Processing and Storage}

On the morning following milk collection, commingled raw milks with four different levels of SCC (batches
A, B, C, and D) were separated (model 100; DeLaval, Poughkeepsie, NY) at $49^{\circ} \mathrm{C}$ into four pairs of skim milk and cream. Fat content of separated creams [(Association of Official Analytical Chemists, 2000); AOAC method number 33.3.18; 995.18] and skim milks [(Marshall, 1993); method number 15.8B] were determined by the Babcock method. The lowest and highest SCC batches (A and D) were standardized to 1, 2, and 3.25\% fat (using the cream that originated from that batch), while the intermediate SCC batches (B and C) were only standardized to $2 \%$ fat. This produced the starting milks for all three experiments.

Standardized raw milk was homogenized (first stage $13.8 \mathrm{MPa}$, second stage $3.5 \mathrm{MPa})$ at $60^{\circ} \mathrm{C}$ (model $75 \mathrm{E}$, Gaulin, Everett, MA), immediately pasteurized (HTST, $76^{\circ} \mathrm{C} / 30 \mathrm{~s}$ ) in shell and tube pasteurizer and cooled to $4^{\circ} \mathrm{C}$. This temperature and time was used to simulate the average heat exposure used by commercial fluid milk processing plants (Ma et al., 2000). Pasteurization was confirmed by the Phosphatase Test (Sharer Modified Phosphatase Test model D kit; Applied Research Institute, Perth Amboy, NJ). Efficiency of homogenization was determined by measuring fat globule size distribution (Smith et al., 1995) using a laser light-scattering particle size analyzer (MasterSizer model E; Malvern, Worcestershire, UK). Fat content was determined after pasteurization using the Mojonnier method [(Association of Official Analytical Chemists, 2000); AOAC method number 33.2.26; 989.05].

After pasteurization, milks from all treatments were preserved using potassium dichromate $(0.2 \mathrm{mg} / \mathrm{kg}$ of milk) and stored in 30-ml plastic vials (Capitol Vial Corp., Fultonville, NY) at either 0.5 or $6^{\circ} \mathrm{C}$. Unpreserved samples were also prepared using $2 \%$ fat milk from batch $\mathrm{A}$ and $\mathrm{D}$, and were stored at both 0.5 and $6^{\circ} \mathrm{C}$ for $29 \mathrm{~d}$ or until the standard plate count (SPC) reached $10^{6} \mathrm{cfu} / \mathrm{ml}$. The complete milk collection, processing, and storage analysis was done twice starting from milks collected from different groups of cows.

\section{Milk Analysis}

Commingled raw milks with four different SCC levels (batches A, B, C, and D) and standardized unpasteurized milks were analyzed in duplicate for SCC [(Association of Offocial Analytical Chemists, 2000); AOAC method number 17.13.01, 978.26], FFA concentration expressed as meq FFA/kg of milk using the copper soap method (Shipe, 1980) as modified by Ma et al. (2003), total nitrogen (TN) [(Association of Official Analytical Chemists, 2000); AOAC method number 33.2.11; 991.20], NPN [(Association of Official Analytical Chemists, 2000); AOAC method number 33.2.12; 991.21], and noncasein nitrogen (NCN) [(Association of Official Ana- 
Table 1. Experiments 1 and 2: ANOVA models used for analysis of the effect of milk SCC levels and temperature of storage $\left(0.5\right.$ and $\left.6^{\circ} \mathrm{C}\right)$ on proteolysis and lipolysis of preserved pasteurized milk containing $2 \%$ fat and for analysis of the effect of milk SCC levels (A, and D) and fat content (1, 2, and 3.25\%) on proteolysis and lipolysis of preserved pasteurized milk at $6^{\circ} \mathrm{C}$.

\begin{tabular}{|c|c|c|c|c|c|c|}
\hline \multirow{2}{*}{$\begin{array}{l}\text { Independent } \\
\text { variables }\end{array}$} & \multicolumn{2}{|c|}{ Experiment $1^{(1)}$} & \multicolumn{2}{|c|}{ Experiment $2^{(2)}$} & \multirow[b]{2}{*}{ Analyzed as } & \multirow[b]{2}{*}{ Error Term } \\
\hline & Table 3 & Table 5 & Table 4 & Table 6 & & \\
\hline & $\longrightarrow$ & 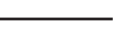 & & $\overline{-}$ & & \\
\hline \multicolumn{7}{|l|}{ Whole plot } \\
\hline $\operatorname{Rep}^{3}$ & 1 & 1 & 1 & 1 & Random & \\
\hline $\mathrm{SCC}$ & 3 & 1 & 1 & 1 & Continuous & E (a) \\
\hline Fat $^{4}$ & $\ldots$ & & 2 & 2 & Categorical & E (a) \\
\hline Temp & $\ldots$ & 1 & $\ldots$ & $\ldots$ & Categorical & $\mathrm{E}(\mathrm{a})$ \\
\hline SCC*Temp & $\ldots$ & 1 & $\ldots$ & . & Interaction & E (a) \\
\hline SCC*Fat & $\ldots$ & & $\ldots$ & 2 & Interaction & $\mathrm{E}(\mathrm{a})$ \\
\hline $\mathrm{E}(\mathrm{a})^{5}$ & 3 & 2 & 7 & $\overline{5}$ & Whole plot error & \\
\hline \multicolumn{7}{|l|}{ Sub-subplot } \\
\hline Day $^{6}$ & $\ldots$ & 1 & $\ldots$ & 1 & Continuous & $\mathrm{E}(\mathrm{b})$ \\
\hline Day quadratic & $\ldots$ & 1 & $\ldots$ & $\ldots$ & Continuous & $\mathrm{E}(\mathrm{b})$ \\
\hline Day*Temp & $\ldots$ & 1 & $\ldots$ & $\ldots$ & Interaction & $\mathrm{E}(\mathrm{b})$ \\
\hline Day*Temp*SCC & $\ldots$ & 1 & $\ldots$ & & Interaction & $\mathrm{E}(\mathrm{b})$ \\
\hline Day*SCC & $\ldots$ & 1 & $\ldots$ & 1 & Interaction & $\mathrm{E}(\mathrm{b})$ \\
\hline Day*Fat & $\ldots$ & $\ldots$ & $\ldots$ & 2 & Interaction & $\mathrm{E}(\mathrm{b})$ \\
\hline Day*SCC*Fat & $\ldots$ & & $\ldots$ & 2 & Interaction & $\mathrm{E}(\mathrm{b})$ \\
\hline $\mathrm{E}(\mathrm{b})$ & $\cdots$ & 276 & $\cdots$ & 90 & Subplot error & \\
\hline Total & 7 & 287 & 11 & 117 & & \\
\hline \multicolumn{7}{|c|}{$\begin{array}{l}{ }^{1} \text { Model equation: } \mathrm{Y}=\mathrm{Rep}+\mathrm{SCC}+\text { Temp }+ \text { Temp*SCC }+\mathrm{E}(\mathrm{a})+\text { Day }+ \text { Day*SCC + Day*Temp }+ \\
\text { Day*Temp*SCC }+\mathrm{E}(\mathrm{b}) .\end{array}$} \\
\hline \multirow{2}{*}{\multicolumn{7}{|c|}{$\begin{array}{l}{ }^{2} \text { Model equation: } \mathrm{Y}=\mathrm{Rep}+\mathrm{SCC}+\mathrm{Fat}+\mathrm{E}(\mathrm{a})+\text { Day }+ \text { Day*SCC }+ \text { Day*Fat + Day*SCC*Fat + E }(\mathrm{b}) \\
{ }^{3} \text { Rep }=\text { replication. }\end{array}$}} \\
\hline & & & & & & \\
\hline \multicolumn{7}{|c|}{${ }^{4} \mathrm{Fat}=$ fat content $(1,2$ and $3.25 \%)$} \\
\hline \multicolumn{7}{|c|}{${ }^{5}$ Error $(\mathrm{a})=$ Rep $*$ SCC $*$ Fat } \\
\hline${ }^{6}$ Day $=$ time of $s$ & age (day & & & & & \\
\hline
\end{tabular}

lytical Chemists, 2000); AOAC method number 33.2.64; 998.05]. All nitrogen results were expressed as a protein equivalent using a conversion factor of 6.38. Calculations for content of true protein (TP) and CN were, respectively, $(\mathrm{TN}-\mathrm{NPN}) \times 6.38$ and $(\mathrm{TN}-\mathrm{NCN}) \times 6.38$. $\mathrm{CN} / \mathrm{TP}$ was calculated. Increase in FFA concentration was used as an index of lipolysis and CN/TP was used as an index of proteolysis. Commingled raw milk and standardized raw milks were also analyzed for microbial count by SPC, coliform count (CC), and psychrotrophic bacterial count (PBC) (Marshall, 1993).

In experiment 1 , preserved $2 \%$ fat pasteurized milks (batches A, B, C, and D) were stored at either 0.5 or $6^{\circ} \mathrm{C}$ and analyzed on d 1, 5, 8, 12, 15, 19, 22, 26, 29, $33,36,40,43,47,50,54,57$, and 61 for FFA and NCN. In experiment 2, preserved 1, 2, and $3.25 \%$ fat milks were stored at $6^{\circ} \mathrm{C}$ (batches $\mathrm{A}$ and D), and FFA and NCN were measured on days $1,8,15,22,29,36,43,50$, and 57 after pasteurization. In experiment 3 , preserved and unpreserved $2 \%$ fat milks were stored at either 0.5 or $6^{\circ} \mathrm{C}$ (batches A and D), and FFA and NCN were measured on days $1,5,8,12,15,19,22,26$, and 29 after pasteurization. TN and NPN were only measured on $\mathrm{d} 1$ after pasteurization to calculate TP for each batch of milk because these values do not change during storage. The CN/TP were higher, as expected, in the pasteurized standardized milks than in the unpasteurized standardized milks (data not shown). On the last day of storage period, milk samples, preserved and unpreserved, were tested for SPC, CC, and PBC.

\section{Statistical Analysis}

The ANOVA models used for statistical analysis of the initial chemical composition, lipolysis, and proteolysis data are shown in Tables 1 and 2. A split-plot design was used for the analysis of lipolysis and proteolysis, in which SCC level, fat percentage, and milk storage temperature were considered the main plot and storage time as the subplot. SCC data were analyzed using the general linear model procedure of SAS (Version 8.02; SAS Institute Inc., Cary NC). Significance was declared at $P<0.05$.

Because the levels of SCC and days were treated as continuous variables in the ANOVA model for experiment 1 (Table 1), any model terms involving levels of SCC or day and SCC or day interactions would be correlated. For example, the SCC linear and the SCC qua- 
Table 2. Experiment 3: ANOVA models used for analysis of the effect of milk SCC levels (A, and D), temperature of storage $\left(0.5\right.$ and $\left.6{ }^{\circ} \mathrm{C}\right)$, and preservative use on proteolysis and lipolysis of $2 \%$ fat pasteurized milk.

\begin{tabular}{lrll}
\hline Independent variables & df & Analyzed as & Error Term \\
\hline Whole plot & & & \\
Rep $^{1}$ & 1 & Random & \\
SCC & 1 & Categorical & E (a) \\
Temp $^{2}$ & 1 & Categorical & E (a) \\
Pres $^{3}$ & 1 & Categorical & E (a) \\
SCC*Temp & 1 & Interaction & E (a) \\
SCC*Pres & 1 & Interaction & E (a) \\
Temp*Pres & 1 & Interaction & E (a) \\
SCC*Temp*Pres & 1 & Interaction & E (a) \\
E (a) & 7 & Whole plot error & \\
Sub-subplot & & & \\
Day & 1 & Continuous & E (b) \\
Day*SCC & 1 & Interaction & E (b) \\
Day*Temp & 1 & Interaction & E (b) \\
Day*Pres & 1 & Interaction & E (b) \\
Day*Temp*SCC & 1 & Interaction & E (b) \\
Day*Temp*Pres & 1 & Interaction & E (b) \\
Day*SCC*Pres & 1 & Interaction & E (b) \\
Day*SCC*Temp*Pres & 1 & Interaction & E (b) \\
E (b) & 120 & Subplot error & \\
Total & 143 & & \\
\hline
\end{tabular}

${ }^{1} \operatorname{Rep}=$ replication.

${ }^{2} \mathrm{Temp}=$ temperature $\left(0.5\right.$ and $\left.6^{\circ} \mathrm{C}\right)$.

${ }^{3}$ Pres $=$ preservative addition (preserved and unpreserved).

${ }^{4}$ Error (a) $=$ Rep*SCC*Temp*Pres.

${ }^{5}$ Day $=$ time of storage (days).

Model equation; $\mathrm{Y}=\mathrm{Rep}+\mathrm{SCC}+\mathrm{Temp}+$ Pres $+\mathrm{E}(\mathrm{a})+$ Day + Day*SCC + Day*Temp + Day*Pres + Day*SCC*Temp + Day*SCC* Pres + Day*Temp*Pres + Day*SCC*Temp*Pres + E (b).

dratic would be correlated. Distortion of the ANOVA by multicollinearity of these terms in the model was minimized by centering the levels of SCC and days data using a mathematical transformation of the data for SCC and days (Glantz and Slinker, 2001). The transformation was done by subtracting the mean (SCC or day) from each of the individual levels of SCC or days and using these "mean-centered" data in the statistical analysis. This type of linear transformation minimized correlation between the model terms involving levels of SCC and days but did not alter the mathematical nature of the statistical testing (Glantz and Slinker, 2001). In experiments 2 and 3, there were only two somatic cell levels, so SCC was treated as category variable, while day was treated as a continuous variable (Tables 1 and 2). However, the values for day were "mean centered" before ANOVA as done for data in experiment 1 .

\section{RESULTS AND DISCUSSION}

\section{Raw Milk SCC}

The mean SCC of the four unstandardized raw milks before processing were $26,000,376,000,726,000$, and
$1,113,000$ cells/ml for milks A, B, C, and D, respectively. These SCC represent a wide range of raw milk quality that can be encountered in the dairy industry.

\section{Standardized Milk Composition and SCC}

Experiments 1 and 3. All standardized pasteurized milks were phosphatase negative. The mean standardized milk compositions before pasteurization (i.e., FFA, $\mathrm{CP}$, TP, casein, and CN/TP) and indices of fat globule size distribution (i.e., volume mean diameter (VMD), and the diameter of globule below which $90 \%$ of the volume of fat is contained [D (0.9)] are presented in Table 3. No effect of SCC $(P>0.05)$ on initial FFA, CP, TP, VMD, and D (0.9) of standardized milk containing $2 \%$ fat prior pasteurization were detected in experiments 1 and 3 (Table 3). Significant effects of SCC on $\mathrm{CN}$ and $\mathrm{CN} / \mathrm{TP}$ were detected with the lowest SCC level (A) having the highest $(82.25 \%) \mathrm{CN} / \mathrm{TP}$ and the highest SCC level (D) having the lowest (80.11\%) CN/TP (Table 3). The mean CN/TP in the present study was lower for high SCC milk than the low SCC milk, and this is consistent with previous reports (Munro et al., 1984; Barbano et al., 1991; Klei et al., 1998). The decrease in CN/TP with increasing milk SCC was due to the proteolysis of casein (Senyk et al., 1985). Plasmin, the main native proteinase responsible for casein breakdown in milk, causes proteolysis of casein in the udder prior to milking during mastitis (Saeman et al., 1988; Murphy et al., 1989; Verdi and Barbano, 1991).

Experiment 2. All standardized pasteurized milks were phosphatase negative. In experiment 2 , significant effects of SCC and fat content on FFA content of milk were detected (Table 4). Milk A $(26,000$ cell $/ \mathrm{ml})$ with $1 \%$ milk fat had the lowest mean FFA (0.09 meq/ $\mathrm{kg}$ of milk), while milk D $(1,113,000 \mathrm{cell} / \mathrm{ml})$ with $3.25 \%$ milk fat had the highest FFA concentration $(0.23$ meq/ $\mathrm{kg}$ of milk) (Table 4). The results are consistent with those of Murphy et al. (1988) and Ma et al. (2000). No effects $(P>0.05)$ of SCC and or fat level on VMD and $\mathrm{D}(0.9)$ of standardized milk were detected. Milk SCC level had a significant effect on CP, TP, CN, and CN/ TP but no effect of milk fat level was detected.

\section{Experiment 1: Proteolysis and Lipolysis in $2 \%$ Fat Milks}

Proteolysis of pasteurized preserved milk. There was a significant effect $(P<0.05)$ of SCC, temperature, storage time (i.e., day), and all the interactions involving time of storage on the proteolysis (i.e., decrease in $\mathrm{CN} / \mathrm{TP}$ ) of pasteurized preserved milk containing $2 \%$ fat (Table 5). The decreases in CN/TP during storage period at 0.5 and $6^{\circ} \mathrm{C}$ are shown in Figure 1. For the 
Table 3. Experiments 1 and 3: Effect of raw milk SCC on standardized 2\% fat milk composition $(\mathrm{n}=2)$.

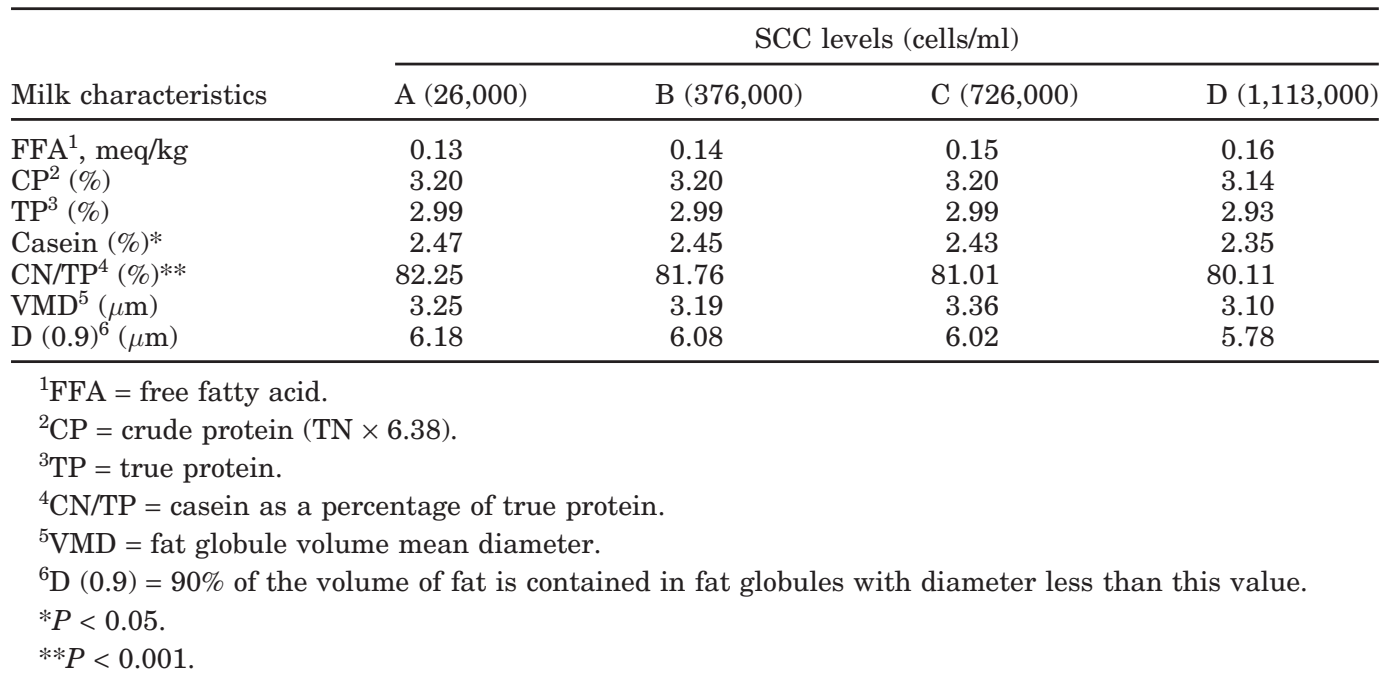

milk from SCC level A $(\mathrm{SCC}=26,000$ cells $/ \mathrm{ml})$, the mean decreases in CN/TP for the 61-d period were 1.45 and $5.94 \%$, for temperature 0.5 and $6^{\circ} \mathrm{C}$, respectively. For the milk from SCC level B (SCC $=376,000$ cells/ $\mathrm{ml}$ ) the mean decreases in CN/TP for the 61-d period were 3.14 and $12.33 \%$, for temperature 0.5 and $6^{\circ} \mathrm{C}$, respectively. For the milk from SCC level $\mathrm{C}$ ( $\mathrm{SCC}=$ 726,000 cells $/ \mathrm{ml}$ ) the mean decreases in CN/TP for the 61 -d period were 4.05 and $14.77 \%$, for temperature 0.5 and $6^{\circ} \mathrm{C}$, respectively. For the milk from SCC level D ( $\mathrm{SCC}=1,113,000$ cells $/ \mathrm{ml}$ ) the mean decreases in $\mathrm{CN} /$ TP for the 61-d period were 6.05 and $16.98 \%$, for temperature 0.5 and $6^{\circ} \mathrm{C}$, respectively. As SCC increased both the rate and extent of proteolysis increased at both 0.5 and $6^{\circ} \mathrm{C}$, but the increases were much larger at $6^{\circ} \mathrm{C}$ than at $0.5^{\circ} \mathrm{C}$. There was a trend $(P=0.089)$ for a
SCC *Temperature interaction on proteolysis, as shown in Figure 2. The decrease in CN/TP going from 26,000 to 376,000 cells $/ \mathrm{ml}$ at $61 \mathrm{~d}$ of storage (Figure 1) was only $1.69 \%$ at $0.5^{\circ} \mathrm{C}$, but at $6^{\circ} \mathrm{C}$, the decrease in $\mathrm{CN} / \mathrm{TP}$ was $6.39 \%$. At higher storage temperature (i.e., $6^{\circ} \mathrm{C}$, more typical of supermarket conditions) the importance of maintaining a very low SCC is more critical. These data clearly show the importance of storage temperature in minimizing proteolysis. Results of the proteolysis from the present study are similar with those reported by Senyk et al. (1985). The significant effect of storage time on the decrease of CN/TP for pasteurized milk indicated that the proteolytic activity of milk remained after pasteurization. The milk was preserved, therefore there was no contribution of microbial proteases, and so the proteolytic activity during storage was

Table 4. Experiment 2: Effect of fat level and raw milk SCC on the initial standardized unpasteurized milk mean composition $(\mathrm{n}=2)$.

\begin{tabular}{|c|c|c|c|c|c|c|c|c|c|c|}
\hline \multirow{3}{*}{$\begin{array}{l}\text { Milk } \\
\text { characteristics }\end{array}$} & \multirow{2}{*}{\multicolumn{3}{|c|}{$\frac{\mathrm{A}(26,000 \text { cells } / \mathrm{ml})}{\text { Fat levels }(\%)}$}} & \multirow{2}{*}{\multicolumn{3}{|c|}{$\frac{\mathrm{D}(1,113,000 \text { cells/ml })}{\text { Fat levels }(\%)}$}} & \multirow{3}{*}{$\begin{array}{l}\text { Fat } \\
P\end{array}$} & \multirow{2}{*}{\multicolumn{2}{|c|}{ SCC level }} & \multirow{3}{*}{$\begin{array}{l}\text { SCC } \\
P\end{array}$} \\
\hline & & & & & & & & & & \\
\hline & 1 & 2 & 3.25 & 1 & 2 & 3.25 & & $\begin{array}{l}\text { A } \\
\text { Mean }\end{array}$ & $\begin{array}{l}\text { D } \\
\text { Mean }\end{array}$ & \\
\hline $\mathrm{FFA}^{1}, \mathrm{meq} / \mathrm{kg}$ & 0.09 & 0.12 & 0.17 & 0.11 & 0.16 & 0.23 & $<0.001$ & 0.13 & 0.16 & 0.003 \\
\hline $\mathrm{CP}^{2}(\%)$ & 3.24 & 3.20 & 3.22 & 3.16 & 3.14 & 3.12 & NS & 3.22 & 3.13 & 0.013 \\
\hline $\mathrm{TP}^{3}(\%)$ & 3.03 & 2.99 & 3.02 & 2.94 & 2.93 & 2.92 & NS & 3.02 & 2.93 & 0.008 \\
\hline Casein (\%) & 2.50 & 2.47 & 2.48 & 2.35 & 2.35 & 2.33 & NS & 2.48 & 2.34 & $<0.001$ \\
\hline $\mathrm{CN} / \mathrm{TP}^{4}(\%)$ & 82.34 & 82.27 & 82.20 & 79.81 & 80.12 & 79.99 & NS & 82.26 & 79.99 & $<0.001$ \\
\hline $\operatorname{VMD}^{5}(\mu \mathrm{m})$ & 3.16 & 3.25 & 3.44 & 3.19 & 3.10 & 3.18 & NS & 3.28 & 3.15 & NS \\
\hline $\mathrm{D}(0.9)^{6}(\mu \mathrm{m})$ & 6.23 & 6.18 & 6.12 & 5.96 & 5.78 & 5.76 & NS & 6.17 & 5.83 & NS \\
\hline
\end{tabular}

${ }^{1} \mathrm{FFA}=$ free fatty acid.

${ }^{2} \mathrm{CP}=$ crude protein $(\mathrm{TN} \times 6.38)$.

${ }^{3} \mathrm{TP}=$ true protein.

${ }^{4} \mathrm{CN} / \mathrm{TP}=$ casein as a percentage of true protein.

${ }^{5} \mathrm{VMD}=$ fat globule volume mean diameter, $\mathrm{D}[4,3]$.

${ }^{6} \mathrm{D}(0.9)=90 \%$ of the volume of fat is contained in fat globules with diameter less than this value. 
Table 5. Experiment 1: Type III sum of squares (SS) and probabilities $(P)$ for proteolysis and lipolysis for preserved, pasteurized, homogenized $2 \%$ fat milk stored at two temperatures $\left(0.5\right.$ and $\left.6^{\circ} \mathrm{C}\right)$ for $61 \mathrm{~d}$.

\begin{tabular}{|c|c|c|c|c|c|}
\hline \multirow{2}{*}{$\begin{array}{l}\text { Independent } \\
\text { variables }\end{array}$} & \multirow[b]{2}{*}{$\mathrm{df}$} & \multicolumn{2}{|c|}{ Proteolysis } & \multicolumn{2}{|c|}{ Lipolysis } \\
\hline & & SS & $\mathrm{P}$ & SS & $\mathrm{P}$ \\
\hline \multicolumn{6}{|l|}{ Whole-plot factor } \\
\hline $\operatorname{Rep}^{1}$ & 1 & 0.44 & 0.319 & 0.0006 & 0.219 \\
\hline $\mathrm{SCC}$ & 1 & 691 & 0.021 & 0.14 & 0.012 \\
\hline $\mathrm{Temp}^{2}$ & 1 & 1236 & 0.012 & 0.16 & 0.010 \\
\hline SCC*Temp & 1 & 149 & 0.089 & 0.01 & 0.134 \\
\hline Error (a) & 2 & 30 & & 0.01 & \\
\hline \multicolumn{6}{|l|}{ Subplot factor } \\
\hline Day $^{3}$ & 1 & 16,943 & $<0.001$ & 0.30 & $<0.001$ \\
\hline Day quadratic & 1 & 4 & 0.003 & 0.01 & 0.040 \\
\hline Day*SCC & 1 & 226 & $<0.001$ & 0.02 & $<0.001$ \\
\hline Day*Temp & 1 & 534 & $<0.001$ & 0.09 & $<0.001$ \\
\hline Day*SCC*Temp & 1 & 39 & $<0.001$ & 0.01 & $<0.001$ \\
\hline Error (b) & 276 & 121 & & 0.13 & \\
\hline $\mathrm{R}^{2}$ & & 0.97 & & 0.85 & \\
\hline
\end{tabular}

due to plasmin and proteases from somatic cells. After the $61 \mathrm{~d}$ of storage, the average of SPC, PBC, and CC of preserved, pasteurized milks containing $2 \%$ fat were $<190,<10$, and $<1 \mathrm{cfu} / \mathrm{ml}$ for all SCC levels (i.e., milks $\mathrm{A}, \mathrm{B}, \mathrm{C}$, and D) at both temperatures of storage (i.e., 0.5 and $\left.6^{\circ} \mathrm{C}\right)$. The proteolytic damage to casein in pasteurized milk increased with increasing milk SCC. This was probably due to a higher concentration of plasmin,
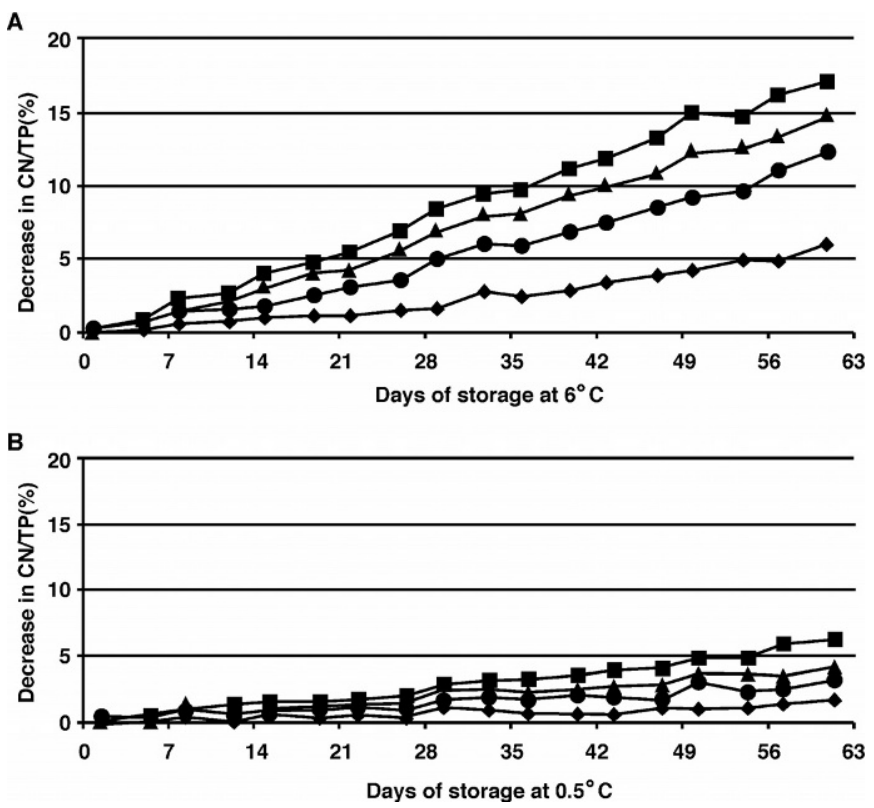

Figure 1. Experiment 1: Effect of SCC $(\bullet=26,000, \bullet=376,000$, $\boldsymbol{\Delta}=726,000$, and $\boldsymbol{\square}=1,113,000$ cell $\mathrm{s} / \mathrm{ml})$ on mean proteolysis of $2 \%$ fat preserved milk at $6^{\circ} \mathrm{C}(\mathrm{A})$ and $0.5^{\circ} \mathrm{C}(\mathrm{B})$. plasminogen (the zymogen form of plasmin), and higher rate of conversion of plasminogen to plasmin in high SCC milk, as reported by Zachos et al. (1992).

Based on the previous work by Santos et al. (2003), an off-flavor due to proteolysis was detected by $50 \%$ of panelists when the decrease in CN/TP was higher than $4.76 \%$. It can be estimated from data (Figure 1) in the present study (assuming 50\% of consumers would detect an off-flavor when CN/TP decreases $5 \%$ ) that pasteurized milk containing $2 \%$ fat would have an off-flavor at much later than 61 and at $54 \mathrm{~d}$ for the low SCC milk

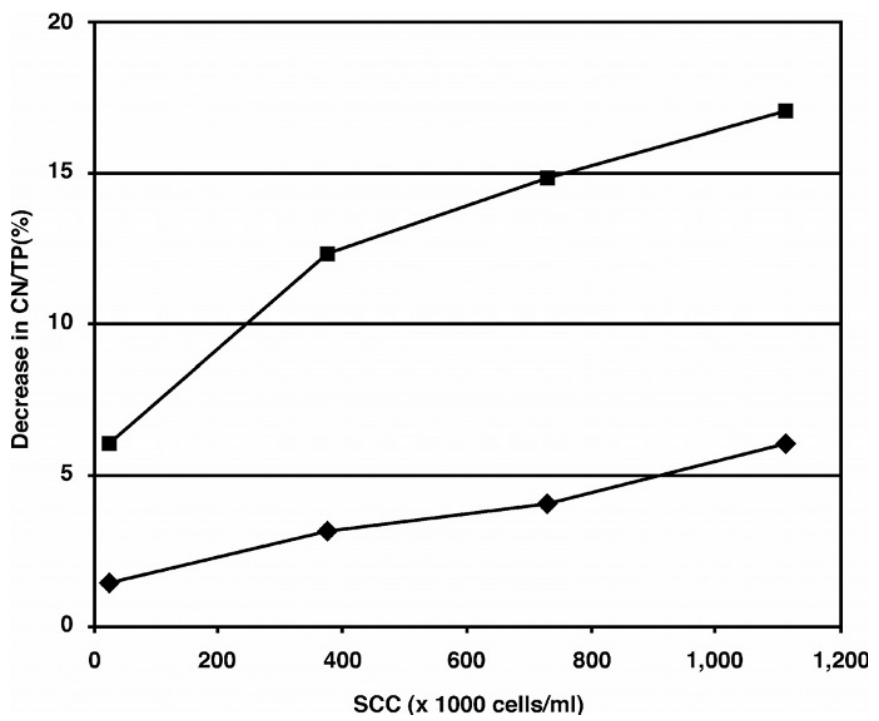

Figure 2. Experiment 1: Mean proteolysis of milks with different SCC levels at $61 \mathrm{~d}$ of storage at $6(\mathbf{\square})$ and $0.5^{\circ} \mathrm{C}(\bullet)$. 
A

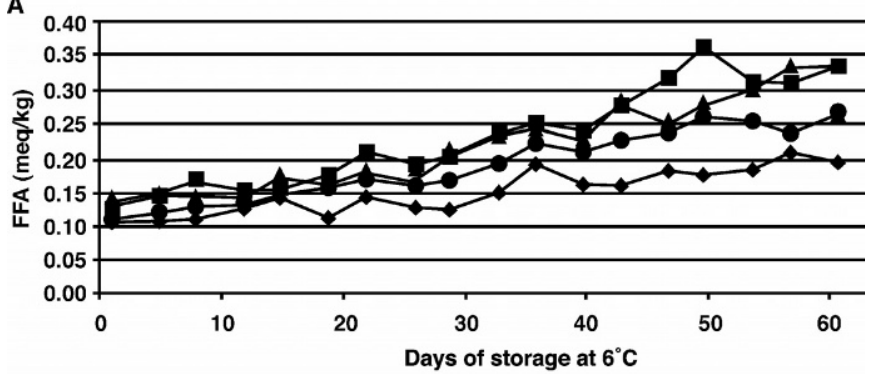

B

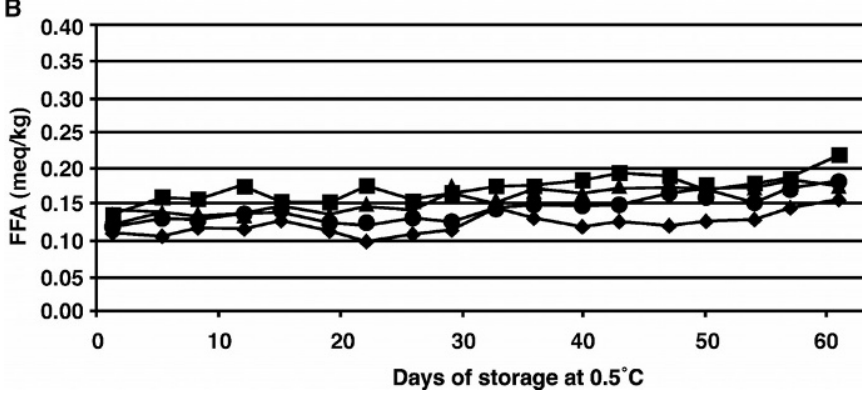

Figure 3. Experiment 1: Effect of SCC $(\bullet=26,000, \bullet=376,000$, $\boldsymbol{\Delta}=726,000$, and $\boldsymbol{\nabla}=1,113,000 \mathrm{cell} \mathrm{s} / \mathrm{ml}$ ) on mean lipolysis of $2 \%$ fat preserved milk at $6(\mathrm{~A})$ and $0.5^{\circ} \mathrm{C}(\mathrm{B})$.

(Figure 1B), and at about 54 and at $19 \mathrm{~d}$ for the high SCC (Figure 1A), at 0.5 and $6^{\circ} \mathrm{C}$, respectively. These results are for preserved milks, but they indicate the potential for maintaining freedom from off-flavors during shelf-life when microbial growth is minimized or eliminated by improved processing technology.

Lipolysis of pasteurized preserved milk. Lipolysis was significantly $(P<0.05)$ affected by SCC, tempera- ture, and storage time (i.e., day), but not by the SCC*Temp interaction, as shown in Table 5. The increase in FFA concentration during the 61-d storage period is shown in Figure 3. The high SCC pasteurized milk was more susceptible to lipolysis than low SCC milk, which agrees with previous results (Ma et al., 2000).

In the present study, the increase in FFA concentration was observed at both temperatures of storage ( 0.5 and $6^{\circ} \mathrm{C}$ ); however, higher levels of FFA were observed at $6^{\circ} \mathrm{C}$ for milk with high $\mathrm{SCC}$ (Figure $3 \mathrm{~A}$ ). In agreement with the findings of the present study, Bachman et al. (1988) found that the FFA concentration in milk was positively correlated with SCC. The occurrence of lipolysis in pasteurized preserved milk containing $2 \%$ fat during storage indicated that lipolytic enzymes in milk associated with high SCC can survive pasteurization, as reported by Shipe and Senyk (1981) and (Ma et al. (2000). In the milk from healthy quarters, the main lipolytic enzyme in milk is lipoprotein lipase (LPL) (Olivecroma et al., 1992); however, in milk with elevated SCC, the lipases from somatic cells may contribute significantly to lipolysis during refrigerated storage of milk (Azzara and Dimick, 1985a, 1985b).

Elevated FFA concentration in milk was associated with a rancid off-flavor (Ma et al., 2000). Previous research (Santos et al., 2003) reported that $34 \%$ of panelists could detect an off-flavor in milk containing $2 \%$ fat due to lipolysis at a FFA concentration of $0.25 \mathrm{meq} / \mathrm{kg}$ of milk. Based on these results, it can be estimated in the present study that $34 \%$ of panelists would have detected an off-flavor in the $2 \%$ fat pasteurized preserved milk with low SCC at a time much longer than

Table 6. Experiment 2: Type III sum of squares (SS), and probabilities $(P)$ for proteolysis and lipolysis for preserved, pasteurized, homogenized milk with two SCC levels (A and D) and 3 fat levels (1, 2, and 3.25\%) stored at $6^{\circ} \mathrm{C}$ for $57 \mathrm{~d}$.

\begin{tabular}{|c|c|c|c|c|c|}
\hline \multirow{2}{*}{$\begin{array}{l}\text { Independent } \\
\text { variables }\end{array}$} & \multirow[b]{2}{*}{$\mathrm{df}$} & \multicolumn{2}{|c|}{ Proteolysis } & \multicolumn{2}{|c|}{ Lipolysis } \\
\hline & & SS & $P$ & SS & $P$ \\
\hline \multicolumn{6}{|l|}{ Whole-plot factor } \\
\hline $\operatorname{Rep}^{1}$ & 1 & 16 & $<0.001$ & 0.01 & $<0.001$ \\
\hline SCC & 1 & 886 & $<0.001$ & 0.11 & $<0.001$ \\
\hline $\mathrm{Fat}^{2}$ & 2 & 27 & 0.035 & 0.41 & $<0.001$ \\
\hline SCC*Fat & 2 & 1 & 0.742 & 0.01 & 0.126 \\
\hline $\mathrm{E}(\mathrm{a})$ & 5 & 9 & & 0.01 & \\
\hline \multicolumn{6}{|l|}{ Subplot factor } \\
\hline Day $^{3}$ & 1 & 1331 & $<0.001$ & 0.23 & $<0.001$ \\
\hline Day*SCC & 1 & 326 & $<0.001$ & 0.01 & 0.002 \\
\hline Day*Fat & 2 & 8 & $<0.001$ & 0.11 & $<0.001$ \\
\hline Day*SCC*Fat & 2 & 1 & 0.298 & 0.01 & 0.116 \\
\hline $\mathrm{E}(\mathrm{b})$ & 90 & 38 & & 0.08 & \\
\hline $\mathrm{R}^{2}$ & & 0.99 & & 0.92 & \\
\hline
\end{tabular}

${ }^{1} \operatorname{Rep}=$ replication.

${ }^{2}$ Fat $=$ milk fat content $(1,2$ and $3.25 \%)$.

${ }^{3}$ Day $=$ time of storage (days). 

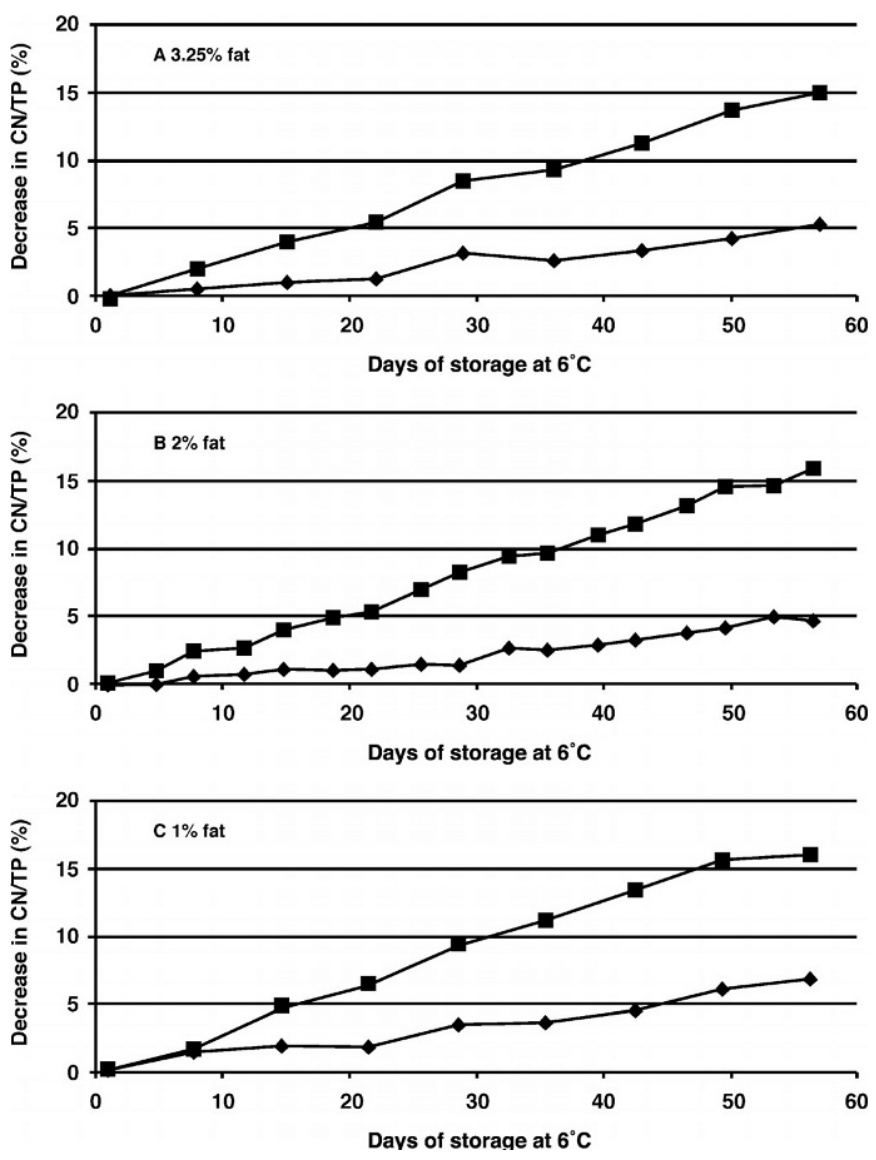

Figure 4. Experiment 2: Effect of SCC $(=26,000$ and $1,113,000$ cells $/ \mathrm{ml}$ ) on proteolysis of $3.25 \%(\mathrm{~A}), 2 \%(\mathrm{~B})$, and $1 \%(\mathrm{C})$ fat preserved milk at $6^{\circ} \mathrm{C}$.

61 and just after $61 \mathrm{~d}$ at 0.5 and $6^{\circ} \mathrm{C}$, respectively, while for milk with high SCC an off-flavor would have been detected by $34 \%$ of panelist at just after 61 and $35 \mathrm{~d}$ at 0.5 and $6^{\circ} \mathrm{C}$, respectively.

If raw milk containing low SCC (i.e., $<50,000$ cells/ $\mathrm{ml}$ ) is kept below $0.5^{\circ} \mathrm{C}$ and microbial growth is prevented, off-flavors due to lipolysis and proteolysis by native milk enzymes will not be detected until long after $61 \mathrm{~d}$ of shelf-life. If low SCC milk is held at $6^{\circ} \mathrm{C}$, off-flavor due to proteolysis and lipolysis (in the absence of microbial growth) will be detected between 50 and $70 \mathrm{~d}$ stored at $6^{\circ} \mathrm{C}$. If high SCC milk (i.e., $>1,000,000$ cells $/ \mathrm{ml}$ ) is stored at $<0.5^{\circ} \mathrm{C}$, off-flavors due to lipolysis and proteolysis will be detected between 50 and $60 \mathrm{~d}$. At $6^{\circ} \mathrm{C}$, off-flavor due to lipolysis would be detected at about $35 \mathrm{~d}$, while off-flavor due to proteolysis would be detected by $50 \%$ of panelists in about $18 \mathrm{~d}$.

\section{Experiment 2: Influence of Fat Level on Proteolysis and Lipolysis}

Proteolysis of pasteurized preserved milk with 1,2 , and $3.25 \%$ fat stored at $6^{\circ} \mathrm{C}$. Results of the ANOVA for the effect of milk SCC and milk fat level on proteolysis and lipolysis in pasteurized milks stored at $6^{\circ} \mathrm{C}$ during a 57-d period are shown in Table 6. A significant effect of replicate, milk SCC, fat level, day, day*SCC, and day*fat on proteolysis were observed (Table 6). The decrease in CN/TP during storage time for experiment 2 is presented in Figure 4 . The effect of fat level on proteolysis was significant (Table 7). The proteolysis was higher for milk containing $1 \%$ fat than milk containing $3.25 \%$ fat at both SCC levels. Valero et al. (2001) also reported higher levels of proteolysis for UHT-treated skim milk than for UHT-treated whole milk. We hypothesize that the mechanism for the reduction in proteolysis with increasing fat content was due to a change in the availability of the casein substrate caused by homogenization. It is well documented (Walstra, 1995) that casein micelles become attached to the interface of milk fat globules as a result of homogenization. This may limit the accessibility of casein to attack by the native milk proteases.

Lipolysis of pasteurized preserved milk with 1, 2, and $3.25 \%$ fat stored at $6^{\circ} \mathrm{C}$. The mean concentration of FFA in pasteurized preserved milk stored at $6^{\circ} \mathrm{C}$ during the 57-d period was significantly affected by all factors studied, including replicate, milk SCC, milk fat level, day, day*SCC, and day*fat, as shown in Table 6. The FFA content in milk with $1 \%$ fat level was lower than for milk with $3.25 \%$ fat in both low and high SCC

Table 7. Experiment 2: Least square mean of the proteolysis (decrease in CN/TP) and lipolysis (meq/kg), by milk SCC levels $(A=26,000$ and $\mathrm{D}=1,113,000$ cells $/ \mathrm{ml})$ and fat content $(1,2$, and $3.25 \%)$ on preserved pasteurized milk at $6^{\circ} \mathrm{C}$ stored for $57 \mathrm{~d}$.

\begin{tabular}{|c|c|c|c|c|c|c|c|c|c|c|}
\hline & $\mathrm{A}($ & $000 \mathrm{cel}$ & (ml) & $\mathrm{D}(1$ & $3,000 \mathrm{c}$ & $\mathrm{s} / \mathrm{ml})$ & & & & \\
\hline & & levels & & & levels & & & NC & & \\
\hline & 1 & 2 & 3.25 & 1 & 2 & 3.25 & $P$ & Mean & Mean & $P$ \\
\hline Proteolysis & $3.19^{\mathrm{a}}$ & $2.12^{\mathrm{b}}$ & $2.24^{\mathrm{b}}$ & $8.99^{\mathrm{a}}$ & $8.07^{b}$ & $7.68^{\mathrm{b}}$ & 0.035 & 2.52 & 8.25 & $<0.001$ \\
\hline Lipolysis & $0.09^{c}$ & $0.15^{\mathrm{b}}$ & $0.22^{\mathrm{a}}$ & $0.12^{\mathrm{c}}$ & $0.22^{\mathrm{b}}$ & $0.31^{\mathrm{a}}$ & $<0.001$ & 0.16 & 0.22 & $<0.001$ \\
\hline
\end{tabular}

${ }^{\mathrm{a}, \mathrm{b}, \mathrm{c}}$ Least square means within each SCC level with different superscript differ $(P<0.05)$. 

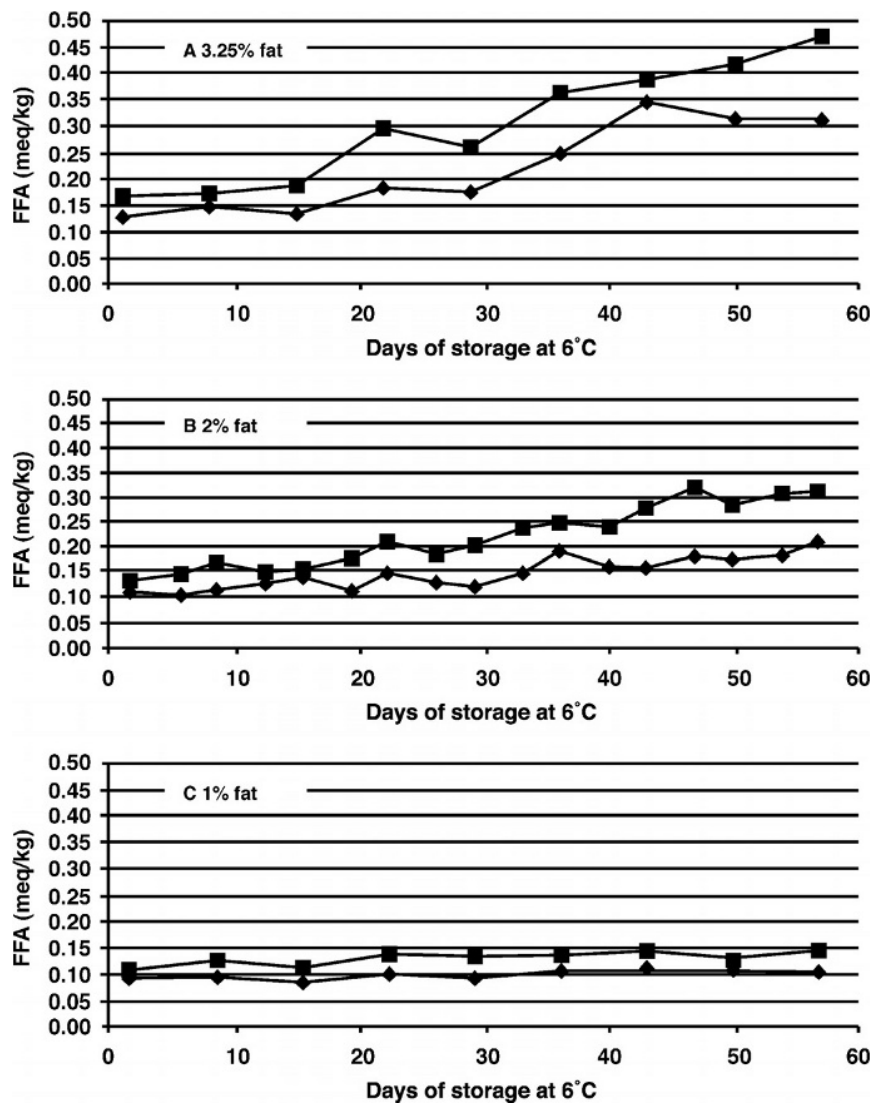

Figure 5. Experiment 2: Effect of SCC $(-26,000$ and $\mathbf{\square}=$ $1,113,000$ cells $/ \mathrm{ml}$ ) on lipolysis of 3.25 (A), 2 (B), and $1 \%$ (C) fat preserved milk at $6^{\circ} \mathrm{C}$.

milks (Figure 5; Table 7). Murphy et al. (1989) also reported an increase in FFA in milk from cows with mastitis when compared to normal milk. Fat concentration in milk had a significant impact (Table 6) on lipolysis in both low and high SCC milk, with both the level (Table 7) and the rate (Figure 5) of increase of FFA content increasing with increasing fat content, when microbial growth was eliminated. After the $57 \mathrm{~d}$ of stor- age at $6^{\circ} \mathrm{C}$, the average of SPC, $\mathrm{PBC}$, and $\mathrm{CC}$ of preserved, pasteurized milks containing $2 \%$ fat were $<10$, $<30$, and $<1 \mathrm{cfu} / \mathrm{ml}$ for all SCC levels (i.e., milks A and D) and for all three fat levels (i.e., 1, 2, and 3.25\%).

\section{Experiment 3: Proteolysis and Lipolysis When Microbial Growth Was Not Inhibited}

Microbial data before and after pasteurization and storage. The mean bacterial counts of the unpasteurized standardized milks immediately before pasteurization were quite low for all treatments, as shown in Table 8. The PBC of $2 \%$ fat unpreserved pasteurized milk stored at 0.5 and $6^{\circ} \mathrm{C}$ for a 29 -d period is presented in Table 9. PBC were below $10^{3} \mathrm{cfu} / \mathrm{ml}$ during the storage time at $0.5^{\circ} \mathrm{C}$; however, for milk stored at $6^{\circ} \mathrm{C}, \mathrm{PBC}$ were $>10^{6} \mathrm{cfu} / \mathrm{ml}$ after d 22 for high SCC milk (D) and after d 26 for low SCC milk (A). Coliform counts were $<1 \mathrm{cfu} / \mathrm{ml}$ for low and high SCC milks at both temperatures $\left(0.5\right.$ and $\left.6^{\circ} \mathrm{C}\right)$ during the $29 \mathrm{~d}$ of storage and $\mathrm{SPC}$ were similar to PBC (data not shown) (Table 9). For preserved portions of the same milk all bacteria counts were $<100 \mathrm{cfu} / \mathrm{ml}$ at both 0.5 and $6^{\circ} \mathrm{C}$.

Proteolysis of preserved and unpreserved pasteurized milk. There was a significant effect $(P<0.05)$ of SCC, temperature, day of storage, and the interactions SCC*temperature, SCC*day, day*temperature, day*SCC*temperature, day*SCC*preserve and day*temperature*preserve on proteolysis of the pasteurized milk containing $2 \%$ fat, as shown in Table 10 . The decrease in CN/TP during the storage period at 0.5 and $6^{\circ} \mathrm{C}$ for preserved and unpreserved milks is shown in Figure 6. Proteolysis was higher for high SCC milk (D) in both temperatures of storage $\left(0.5\right.$ and $\left.6^{\circ} \mathrm{C}\right)$ in both preserved and unpreserved milks (Figure 6). No effect of the use of preservative on proteolysis was detected (Table 10), indicating that the microbial growth had little effect on the total proteolysis up to $\mathrm{d} 19$ of storage at $6^{\circ} \mathrm{C}$, when the $\mathrm{PBC}$ was $<30,000 \mathrm{cfu} / \mathrm{ml}$ (Table 9 ). After d 22, when bacterial count of unpreserved milk

Table 8. Experiments 1, 2, and 3: Mean of standard plate count (SPC), coliform count (CC), and psychrotrophic bacterial count (PBC), expressed as cfu/ml, of unpreserved standardized milk prior to pasteurization $(\mathrm{n}=2)$.

\begin{tabular}{|c|c|c|c|c|c|c|c|c|}
\hline \multirow{4}{*}{$\begin{array}{l}\text { Microbial } \\
\text { counts }\end{array}$} & \multicolumn{8}{|c|}{ SCC levels (cells/ml) } \\
\hline & \multicolumn{3}{|c|}{$\mathrm{A}(26,000)$} & \multirow{3}{*}{$\begin{array}{l}\text { B } \\
(376,000)^{1}\end{array}$} & \multirow{3}{*}{$\begin{array}{l}\mathrm{C} \\
(726,000)^{1}\end{array}$} & \multicolumn{3}{|c|}{$\mathrm{D}(1,113,000)$} \\
\hline & \multicolumn{3}{|c|}{ Fat $(\%)$} & & & \multicolumn{3}{|c|}{ Fat $(\%)$} \\
\hline & 1 & 2 & 3.25 & & & 1 & 2 & 3.25 \\
\hline SPC & 14,550 & 14,550 & 13,850 & 18,500 & 19,500 & 17,500 & 16,500 & 18,000 \\
\hline $\mathrm{CC}$ & $233\left(\mathrm{E}^{2}\right)$ & $368(\mathrm{E})$ & $2595(\mathrm{E})$ & $585(\mathrm{E})$ & $395(\mathrm{E})$ & $95(\mathrm{E})$ & $90(\mathrm{E})$ & $85(\mathrm{E})$ \\
\hline
\end{tabular}

${ }^{1} 2 \%$ milk fat.

${ }^{2} \mathrm{E}=$ estimated, colonies on the dilution counted were $<30$ or $>300$ per plate. 
Table 9. Experiment 3: Mean of psychrotrophic bacterial count (PBC), expressed as $\mathrm{cfu} / \mathrm{ml}$, of low and high SCC pasteurized unpreserved milks containing $2 \%$ fat, stored at 0.5 and $6{ }^{\circ} \mathrm{C}$ during $29 \mathrm{~d}(\mathrm{n}=2)$.

\begin{tabular}{|c|c|c|c|c|}
\hline \multirow{2}{*}{$\begin{array}{l}\text { Day of } \\
\text { storage }\end{array}$} & \multicolumn{2}{|c|}{ A $(26,000$ cells $/ \mathrm{ml})$} & \multicolumn{2}{|c|}{$\mathrm{D}(1,113,000$ cells/ml $)$} \\
\hline & $0.5^{\circ} \mathrm{C}$ & $6^{\circ} \mathrm{C}$ & $0.5^{\circ} \mathrm{C}$ & $6^{\circ} \mathrm{C}$ \\
\hline 1 & $<1$ & $<1$ & $<1$ & $<1$ \\
\hline 5 & $<1$ & $<1$ & 6 & 215 \\
\hline 8 & 6 & 551 & $<10$ & $70,005(\mathrm{E})$ \\
\hline 12 & 61 & 27,524 & $115(\mathrm{E})$ & 25,550 \\
\hline 15 & 211 & 225,000 & $6(\mathrm{E})$ & 285,000 \\
\hline 19 & $7\left(\mathrm{E}_{1}\right)$ & $8000(\mathrm{E})$ & $<1$ & $30,002(\mathrm{E})$ \\
\hline 22 & $951(\mathrm{E})$ & 180,000 & $51(\mathrm{E})$ & $24,003,500(\mathrm{E})$ \\
\hline 26 & $<1$ & $11,000,000$ & $51(\mathrm{E})$ & $9,950,000(\mathrm{E})$ \\
\hline 29 & 413 & $27,000,000^{2}$ & $202(\mathrm{E})$ & $150,000(\mathrm{E})$ \\
\hline
\end{tabular}

${ }^{1} \mathrm{E}=$ estimated; colonies on the dilution counted were $<30$ or $>300$ per plate.

${ }^{2}$ Presence of mold.

was high, proteolysis of high SCC milk at $6^{\circ} \mathrm{C}$ increased very rapidly compared to the preserved milk (Figure $6 \mathrm{~A})$. For milks with low SCC at both temperatures of storage, the rate of proteolysis was similar between preserved and unpreserved milks until d 29 (Figure 6), even though the $\mathrm{PBC}$ were high at $6^{\circ} \mathrm{C}$ (Table 9). The combined effect of microbial growth plus native milk enzymes on proteolysis was larger at 6 than $0.5^{\circ} \mathrm{C}$. The rapid growth of bacteria in the unpreserved milk at $6^{\circ} \mathrm{C}$ after $22 \mathrm{~d}$ of storage in the high SCC milk may be stimulated by the availability of proteolysis products. An off-flavor in the high SCC milk at $6^{\circ} \mathrm{C}$ would be detected at about $15 \mathrm{~d}$ of storage, while no off-flavor in the low SCC would be expected at $28 \mathrm{~d}$ of storage if microbial growth was controlled.

Lipolysis of preserved and unpreserved pasteurized milk. There was a significant effect $(P<0.05)$ of SCC, day, and day*SCC on lipolysis of the pasteurized milk containing $2 \%$ fat, as shown in Table 10 . The increase of FFA content during the storage period at 0.5

Table 10. Experiment 3: Type III sum of squares (SS) and probabilities $(P)$ for proteolysis and lipolysis for $2 \%$ fat preserved and unpreserved pasteurized milk at two milk SCC levels (A and D) and two temperature of storage $\left(0.5\right.$ and $\left.6^{\circ} \mathrm{C}\right)$ during $29 \mathrm{~d}$ of storage.

\begin{tabular}{|c|c|c|c|c|c|}
\hline \multirow{2}{*}{$\begin{array}{l}\text { Independent } \\
\text { variables }\end{array}$} & \multirow[b]{2}{*}{$\mathrm{df}$} & \multicolumn{2}{|c|}{ Proteolysis } & \multicolumn{2}{|c|}{ Lipolysis } \\
\hline & & SS & $P$ & SS & $P$ \\
\hline \multicolumn{6}{|l|}{ Whole-plot factor } \\
\hline $\operatorname{Rep}^{1}$ & 1 & 34 & 0.025 & 0.057 & $<0.001$ \\
\hline SCC & 1 & 301 & 0.003 & 0.14 & 0.017 \\
\hline Temp $^{2}$ & 1 & 205 & 0.009 & 0.05 & 0.116 \\
\hline Pres $^{3}$ & 1 & 25 & 0.248 & 0.03 & 0.204 \\
\hline SCC*Temp & 1 & 100 & 0.040 & 0.02 & 0.260 \\
\hline SCC*Pres & 1 & 23 & 0.263 & 0.01 & 0.372 \\
\hline Temp*Pres & 1 & 18 & 0.316 & 0.03 & 0.226 \\
\hline SCC $*$ Temp*Pres & 1 & 16 & 0.347 & 0.01 & 0.360 \\
\hline $\mathrm{E}(\mathrm{a})$ & 7 & 110 & & 0.12 & \\
\hline \multicolumn{6}{|l|}{ Subplot factor } \\
\hline Day $^{4}$ & 1 & 341 & $<0.001$ & 0.06 & $<0.001$ \\
\hline Day*Day & 1 & 28 & 0.043 & & $\ldots$ \\
\hline Day*SCC & 1 & 198 & 0.002 & 0.04 & 0.05 \\
\hline Day*Temp & 1 & 152 & 0.011 & 0.03 & 0.181 \\
\hline Day*Pres & 1 & 41 & 0.342 & 0.03 & 0.227 \\
\hline Day*SCC*Temp & 1 & 99 & $<0.001$ & 0.02 & 0.445 \\
\hline Day*Temp*Pres & 1 & 36 & 0.023 & 0.01 & 0.693 \\
\hline Day*SCC*Pres & 1 & 35 & 0.026 & 0.02 & 0.512 \\
\hline Day*SCC*Temp*Pres & 1 & 29 & 0.041 & 0.02 & 0.591 \\
\hline $\mathrm{E}(\mathrm{b})$ & 119 & 790 & & 0.16 & \\
\hline $\mathrm{R}^{2}$ & & 0.70 & & 0.81 & \\
\hline
\end{tabular}

${ }^{1}$ Rep $=$ replication.

${ }^{2}$ Temp $=$ temperature of storage $\left(0.5\right.$ and $\left.6^{\circ} \mathrm{C}\right)$.

${ }^{3}$ Pres $=$ preservative use (preserved and unpreserved).

${ }^{4}$ Day $=$ time of storage (days). 

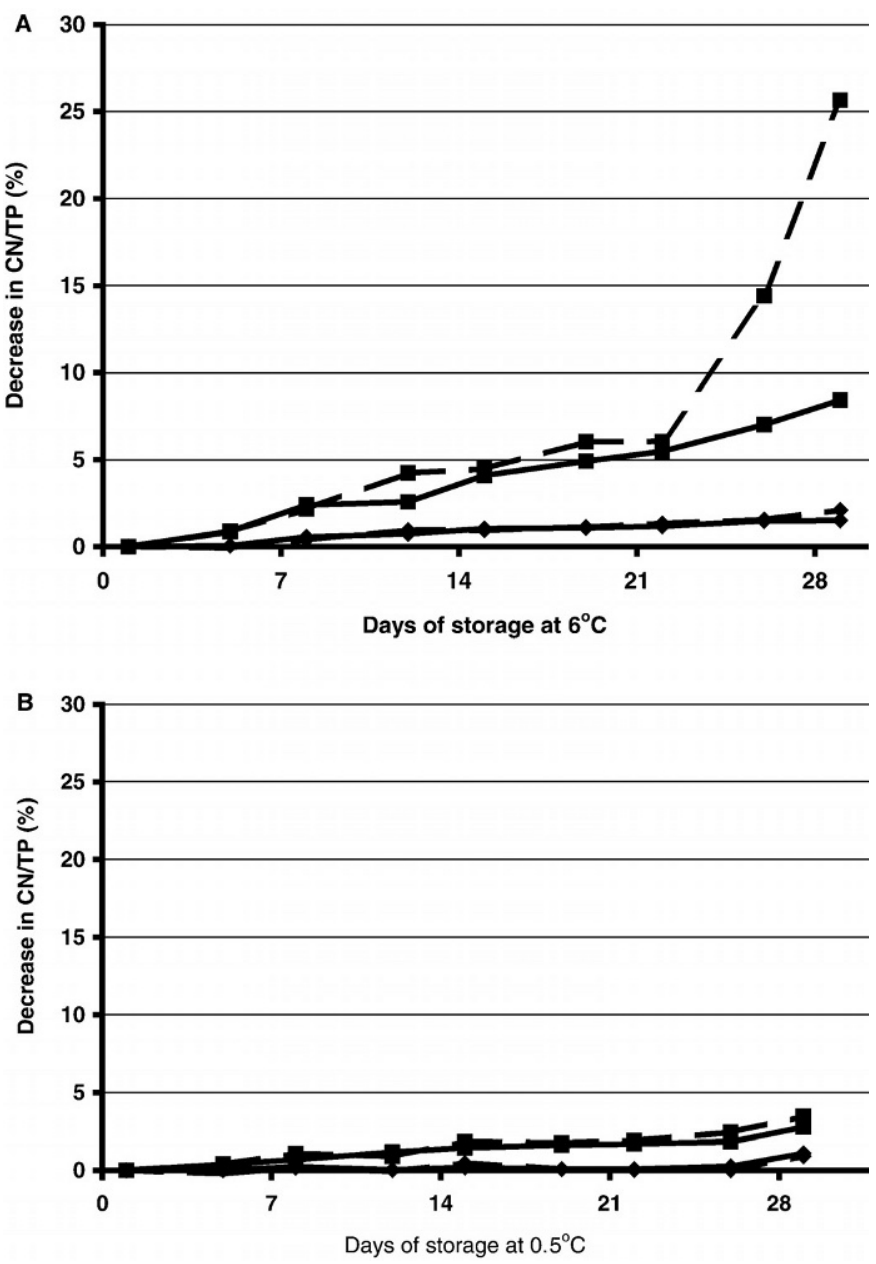

Figure 6. Experiment 3: Effect of SCC on proteolysis of $2 \%$ fat preserved $(=26,000$ and $\mathbf{\square}=1,113,000$ cells $/ \mathrm{ml}$; silid lines $)$ and unpreserved $(-26,000$ and $\boldsymbol{\square}=1,113,000$ cells $/ \mathrm{ml}$; dashed lines $)$ milk at $6^{\circ} \mathrm{C}(\mathrm{A})$ or $0.5^{\circ} \mathrm{C}(\mathrm{B})$.

and $6^{\circ} \mathrm{C}$ for preserved and unpreserved milks is shown in Figure 7. Lipolysis was higher for high SCC milk (D) in both temperatures of storage $\left(0.5\right.$ and $\left.6^{\circ} \mathrm{C}\right)$ in both preserved and unpreserved milks. No effect of the use of preservative on lipolysis was detected, indicating that the microbial growth had little effect on the total lipolysis up to $\mathrm{d} 19$ of storage at $6^{\circ} \mathrm{C}$, when the $\mathrm{PBC}$ was $<30,000 \mathrm{cfu} / \mathrm{ml}$ (Table 9). An off-flavor due to lipolysis in the high SCC milk at $6^{\circ} \mathrm{C}$ would be detected between 8 and $12 \mathrm{~d}$ of shelf-life, even though $\mathrm{PBC}$ was $<70,000$ $\mathrm{cfu} / \mathrm{ml}$, while in the low SCC at $28 \mathrm{~d}$ of storage at $6^{\circ} \mathrm{C}$, no off-flavor due to lipolysis would be detected when microbial growth was minimized.

\section{CONCLUSIONS}

Based on the previous work (Santos et al., 2003), an off-flavor due to proteolysis was detected by $50 \%$ of

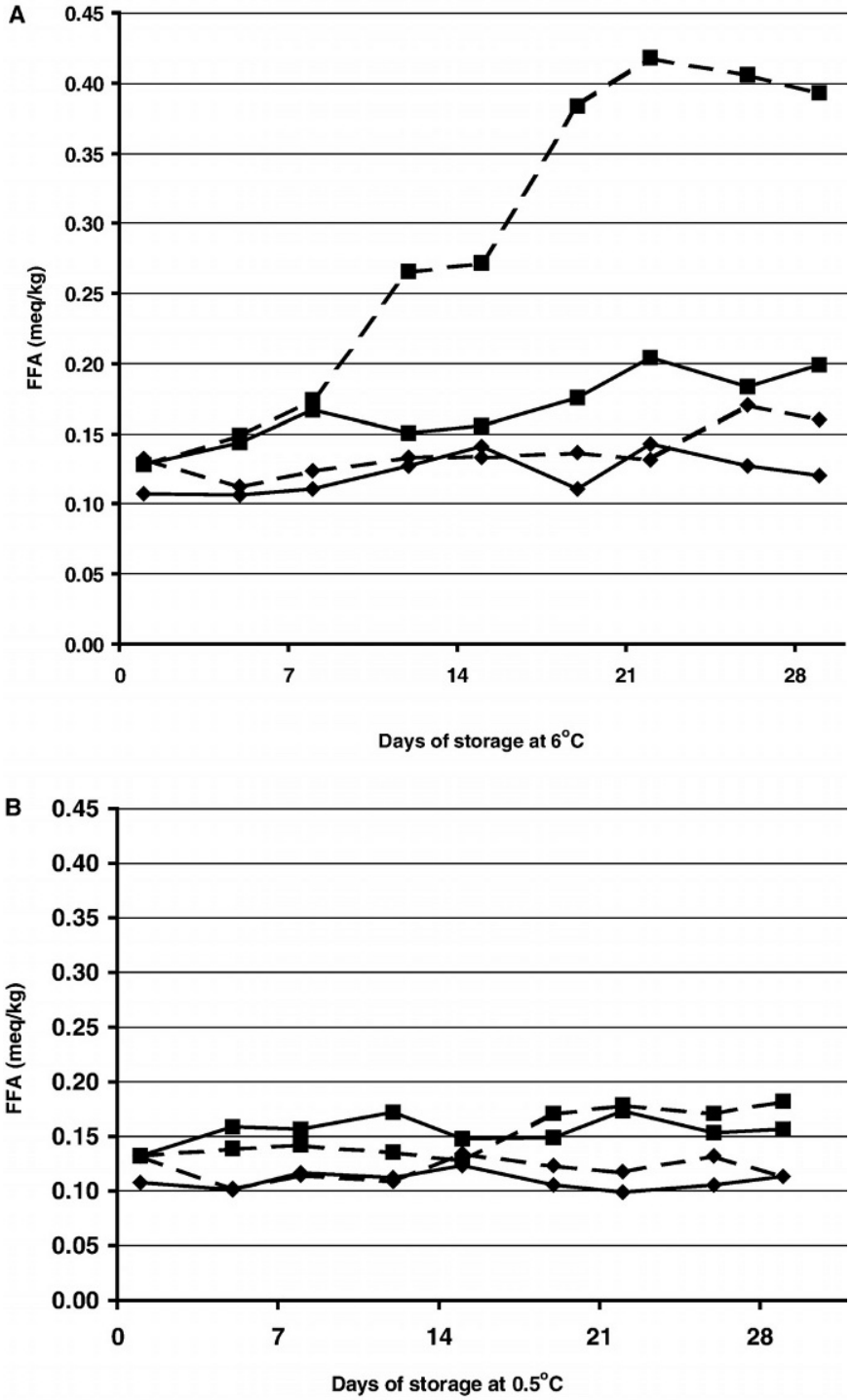

Figure 7. Experiment 3: Effect of SCC on lipolysis of $2 \%$ fat preserved ( $=26,000$ and $\mathbf{\square}=1,113,000 \mathrm{cell} / \mathrm{s} / \mathrm{ml}$; solid lines) and unpreserved ( $=26,000$ and $\boldsymbol{\square}=1,113,000$ cells $/ \mathrm{ml}$; dashed lines) milk at $6^{\circ} \mathrm{C}(\mathrm{A})$ or $0.5^{\circ} \mathrm{C}(\mathrm{B})$.

panelists when the decrease in CN/TP was higher than $4.76 \%$. It was estimated from data in the present study (assuming $50 \%$ of consumers would detect an off-flavor when CN/TP decreases by about 5\%) that pasteurized milk containing $2 \%$ fat would have an off-flavor at a time much greater than 61 and at $54 \mathrm{~d}$ for the low SCC milk if bacteria count is kept below $100,000 \mathrm{cfu} / \mathrm{ml}$, and at about 54 and $19 \mathrm{~d}$ for the high SCC with bacteria count $<100,000 \mathrm{cfu} / \mathrm{ml}$, at 0.5 and $6^{\circ} \mathrm{C}$, respectively. Previous research (Santos et al., 2003) reported that $34 \%$ of panelists could detect an off-flavor in milk containing $2 \%$ fat due to lipolysis at a FFA concentration of 0.25 meq $/ \mathrm{kg}$ of milk. Based on these results, it can be esti- 
mated in the present study that $34 \%$ of panelists would detect an off-flavor in the $2 \%$ fat pasteurized milk with low SCC at a time much greater than 61 and just after $61 \mathrm{~d}$ at 0.5 and $6^{\circ} \mathrm{C}$, respectively, while for milk with high SCC an off-flavor would be detected by $34 \%$ of panelists just after 61 and $35 \mathrm{~d}$ at 0.5 and $6^{\circ} \mathrm{C}$, respectively when bacteria count is kept below 100,000 cfu/ $\mathrm{ml}$. If the pasteurized milk PBC starts out low (i.e., $<1$ $\mathrm{cfu} / \mathrm{ml}$ ), then the combination of low SCC milk (i.e., $<100,000$ cells $/ \mathrm{ml}$ ) and low storage temperature provides the potential for production of fluid milk with a refrigerated shelf-life of greater than $61 \mathrm{~d}$.

\section{ACKNOWLEDGMENTS}

The authors are grateful to the staff at the Cornell Teaching and Research Farm (Ithaca, NY), DairyOne (Ithaca, NY), and Food Science Department Pilot Plant (Ithaca, NY) for their technical assistance. We also would like to thank Tom Burke, Nancy Carey, Maureen Chapman, Bob Kaltaler, Laura Landolf, Joanna Lynch, and Pat Wood for technical support in chemical and microbial analysis. The authors also thank the Northeast Dairy Food Research Center (Ithaca, NY) and the New York State Milk Promotion Board (Albany, NY) for financial support.

\section{REFERENCES}

Association of Official Analytical Chemists International. 2000. Official Methods of Analysis. 17th ed. AOAC, Arlington, VA.

Azzara, C. D., and P. S. Dimick. 1985a. Lipolytic enzymes activity of macrophages in bovine mammary gland secretions. J. Dairy Sci. 68:1804-1812.

Azzara, C. D., and P. S. Dimick. 1985b. Lipoprotein lipase activity of milk from cows with prolonged subclinical mastitis. J. Dairy Sci. 68:3171-3175.

Bachman, K. C., M. J. Hayen, D. Morse, and C. J. Wilcox. 1988. Effect of pregnancy, milk yield and somatic cell count on bovine milk fat hydrolysis. J. Dairy Sci. 71:925-931.

Barbano, D. M., R. R. Rasmussen, and J. M. Lynch. 1991. Influence of milk somatic cell count and milk age on cheese yield. J. Dairy Sci. 74:369-388.

Glantz, S. A., and B. K. Slinker. 2001. Primer of Applied Regression \& Analysis of Variance. 2nd ed. McGraw-Hill Inc., New York.

Grieve, P. A., and B. J. Kitchen. 1985. Proteolysis in milk: The significance of proteinases originating from milk leucocytes and a comparison of the action of Leucocyte, bacterial, and natural milk proteinases on casein. J. Dairy Res. 52:101-112.

Kitchen, B. J. 1981. Reviews of the progress of dairy science: Milk compositional changes and related diagnostic tests. J. Dairy Res. 48:167-188.
Klei, L., J. Yun, A. Sapru, J. Lynch, D. Barbano, P. Sears, and D. Galton. 1998. Effects of milk somatic cell count on Cottage cheese yield and quality. J. Dairy Sci. 81:1205-1213.

Ma, Y., C. Ryan, and D. M. Barbano, D. M. Galton, M. Rudan, and K. Boor. 2000. Effects of somatic cell count on quality and shelflife of pasteurized fluid milk. J. Dairy Sci. 83:264-274.

Ma, Y., D. M. Barbano, and M. V. Santos. 2003. Effect of $\mathrm{CO}_{2}$ addition to raw milk on proteolysis and lipolysis at $4^{\circ} \mathrm{C}$. J. Dairy Sci. $86: 1616-1631$.

Marshall, R. T. 1993. Standard Methods for the Examination of Dairy Products, 16th ed. Am. Publ. Health Assoc., Inc., Washington, DC.

Munro, G. L., P. A. Grieve, and B. J. Kitchen. 1984. Effects of mastitis on milk yield, milk composition, processing properties, and yield and quality of milk products. Aust. J. Dairy Technol. 39:7-16.

Murphy, S. C., K. Cranker, G. F. Senyk, D. M. Barbano, A. I. Saeman, and D. M. Galton. 1989. Influence of bovine mastitis on lipolysis and proteolysis in milk. J. Dairy Sci. 72:620-626.

National Mastitis Council. 1996. Current Concepts of Bovine Mastitis, 4th ed. NMC. Madison, WI.

Olivecroma, T., S. Vilaro, and G. Olivecroma-Bengtsson. 1992. Indigenous enzymes in milk, II Lipases. Pages 292-305 in Advances in Dairy Chemistry. Vol. 1. P. F. Fox, ed. Elsevier Applied Science, New York.

Politis, I., and K. F. Ng Kwai Hang. 1988a. Effects of somatic cell counts and milk composition on cheese composition and cheese making efficiency. J. Dairy Sci. 71:1711-1719.

Politis, I., and K. F. Ng Kwai Hang. 1988b. Association between somatic cell counts of milk and cheese yielding capacity. J. Dairy Sci. 71:1720-1727.

Santos, M. V., Y. Ma, Z. Caplan, and D. M. Barbano. 2003. Sensory threshold of off-flavors caused by proteolysis and lipolysis in milk. J. Dairy Sci. 86:1601-1607.

Saeman, A. I., R. J. Verdi, D. M. Galton, and D. M. Barbano. 1988. Effects of mastitis on proteolytic activity in bovine milk. J. Dairy Sci. 71:505-512.

Senyk, G. F., D. M. Barbano, and W. F. Shipe. 1985. Proteolysis in milk associated with increasing somatic cell counts. J. Dairy Sci. 68:2189-2194.

Shipe, W. F., G. F. Senyk, and K. B. Fountain. 1980. Modified copper soap solvent extraction method for measuring free fatty acids in milk. J. Dairy Sci. 63:193-198.

Shipe, W. F., and G. F. Shenyk. 1981. Effects of processing conditions on lipolysis in milk. J. Dairy Sci. 64:2146-2149.

Smith, E. B., D. M. Barbano, and J. M. Lynch. 1995. Infrared analysis of milk: Effect of homogenizer an optical filter selection on apparent homogenization efficiency and repeatability. J. AOAC 78:1225-1233.

Valero, E., M. Villamiel, B. Miralles, J. Sanz, and I. Martinez-Castro. 2001. Changes in flavour and volatile components during storage of whole and skimmed UHT milk. Food Chem. 72:51-58.

Verdi, R. J., and D. M. Barbano. 1988. Preliminary investigation on the properties of somatic cell proteases. J. Dairy Sci. 71:534-538.

Verdi, R. J., and D. M. Barbano. 1991. Properties of proteases from milk somatic cells and blood leukocytes. J. Dairy Sci. 74:20772081.

Walstra, P. 1995. Physical chemistry of milk fat globules. Pages 131178 in Advanced Dairy Chemistry. Volume 2. Lipids. P. F. Fox, ed. 2nd ed. Chapman \& Hall. London.

Zachos, T., I. Politis, R. C. Gorewit, and D. M. Barbano. 1992. Effects of mastitis on plasminogen activator activity of milk somatic cells. J. Dairy Res. 59:461-467. 